\title{
Identification of interleukin-1 $\beta$ regulated genes in uterine smooth muscle cells
}

\author{
Grégory Chevillard $^{1,2}$, Anna Derjuga ${ }^{1}$, Dominic Devost ${ }^{3}$, Hans H Zingg ${ }^{3}$ and Volker Blank ${ }^{1,2,4}$ \\ ${ }^{1}$ Lady Davis Institute for Medical Research, ${ }^{2}$ Department of Medicine, ${ }^{3}$ Department of Pharmacology and \\ ${ }^{4}$ Department of Physiology, McGill University, 3755 Cote Sainte-Catherine Road, Montreal, Quebec, \\ H3T 1E2 Canada
}

Correspondence should be addressed to V Blank; Email: volker.blank@mcgill.ca

\begin{abstract}

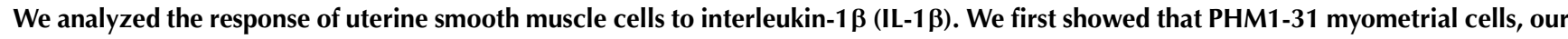
cellular model, are contractile. To determine the molecular mechanisms of uterine smooth muscle cell activation by proinflammatory cytokines, we performed genechip expression array profiling studies of PHM1-31 cells in the absence and the presence of IL-1 $\beta$. In total, we identified 198 known genes whose mRNA levels are significantly modulated ( $>2.0$-fold change) following IL-1 $\beta$ exposure. We confirmed the expression changes for selected genes by independent mRNA and protein analysis. The group of genes induced by IL-1 $\beta$ includes transcription factors and inflammatory response genes such as nuclear factor of $\kappa$ light polypeptide gene enhancer in B-cells (NFKB), pentraxin-related gene (PTX3), and tumor necrosis factor $\alpha$-induced protein 3/A20 (TNFAIP3/A20). We also found up-regulation of chemokines like C-X-C motif ligand 3 (CXCL3) and extracellular matrix remodeling signaling molecules like tenascin C (TNC). Our data suggest that IL-1 $\beta$ elicits the rapid activation of a cellular network of genes particularly implicated in inflammatory response that may create a cellular environment favorable for myometrial cell contraction. Our results provide novel insights into the mechanisms of uterine smooth muscle cell regulation and possibly infection-induced preterm labor.
\end{abstract}

Reproduction (2007) 134 811-822

\section{Introduction}

Proinflammatory cytokines play important roles in a variety of reproductive processes including ovulation, implantation, placentation, cervical dilation, and parturition (Saji et al. 2000, Huang 2006, Romero et al. 2006). Recent evidence suggests that cytokines are involved in events that lead to preterm labor and delivery, particularly in association with intrauterine infection (Goldenberg et al. 2000, Park et al. 2005). Preterm birth, defined as infants who are delivered before 37 weeks of gestation, accounts for $6-10 \%$ of all births and is a major risk factor for infant morbidity and mortality (Slattery \& Morrison 2002). Cervical and intrauterine infection and inflammation in the mother are present in $\sim 30-50 \%$ of preterm labor cases (Gomez et al. 1997, Challis et al. 2002). Bacterial infection leads to the activation of macrophages and lymphocytes. The subsequent release of proinflammatory cytokines such as interleukin-1 $\beta$ (IL-1 $\beta$ ), IL6, tumor necrosis factor $\alpha$ (TNF $\alpha$ ), and the chemotactic protein IL8 attracts additional macrophages as well as eosinophils and neutrophils. The release of proinflammatory cytokines induces phospholipid metabolizing enzymes and the release of prostaglandins (Zaragoza et al. 2006). It has been reported that expression of prostaglandin-endoperoxide synthase 2 gene (PTGS2), a major regulator of parturition, is induced by IL-1 $\beta$, and this induction is accompanied by a threefold increase in prostaglandin E2 ( $\mathrm{PGE}_{2}$; Bartlett et al. 1999, Rauk \& Chiao 2000). In addition, cytokine signaling also activates extracellular matrix (ECM) remodeling enzymes and matrix metalloproteinases. Proinflammatory cytokines are present at the maternal-fetal interface throughout human pregnancy and labor (Lappas et al. 2002). Under normal conditions, elevated levels of IL-1 $\beta$ are observed in amniotic fluid only late in pregnancy. In contrast, upon infection, the levels of IL-1 $\beta$, IL6, TNF $\alpha$, and IL8 are significantly increased, possibly leading to the early onset of labor (Romero et al. 1989, Saji et al. 2000, Suzuki et al. 2006). Recent data in nonhuman primate and mouse models further support the notion that specifically IL- $1 \beta$ and TNF $\alpha$ play a pivotal role in triggering preterm labor (Hirsch et al. 2006, Sadowsky et al. 2006).

In this study, we wanted to further explore the link between the presence of proinflammatory cytokines and myometrial cell function. In particular, we were interested in uncovering the early response of uterine smooth muscle cells to IL-1 $\beta$ exposure. First, we 
demonstrated that PHM1-31 uterine smooth cells are able to contract using a recently developed collagen lattice-based retraction assay. We then performed genome-wide expression profiling of PHM1-31 cells following exposure to IL-1 $\beta$ to identify the network of cytokine-activated genes in uterine smooth muscle cells. Our data suggest that myometrial cells specifically respond to IL-1 $\beta$ resulting in gene expression changes that create an endocrine environment that might promote uterine smooth muscle cell contraction.

\section{Results}

\section{Induction of contraction in PHM1-31 myometrial cells by oxytocin}

PHM1-31 myometrial cells were originally derived from the upper edge of the incision of the uterine segment in a non-labor pregnant woman (Monga et al. 1996). We and others have shown that PHM1-31 cells possess morphological and molecular characteristics typical of myometrial cells (Monga et al. 1996, Massrieh et al. 2006). Recently, a novel in vitro system has been developed to determine whether cells have the ability to contract in response to oxytocin, a potent uterotonic agent (Devost \& Zingg 2007). We used this functional assay to examine the PHM1-31 cell model (Fig. 1A). As observed previously for M11 and hTERT-C3 myometrial cells
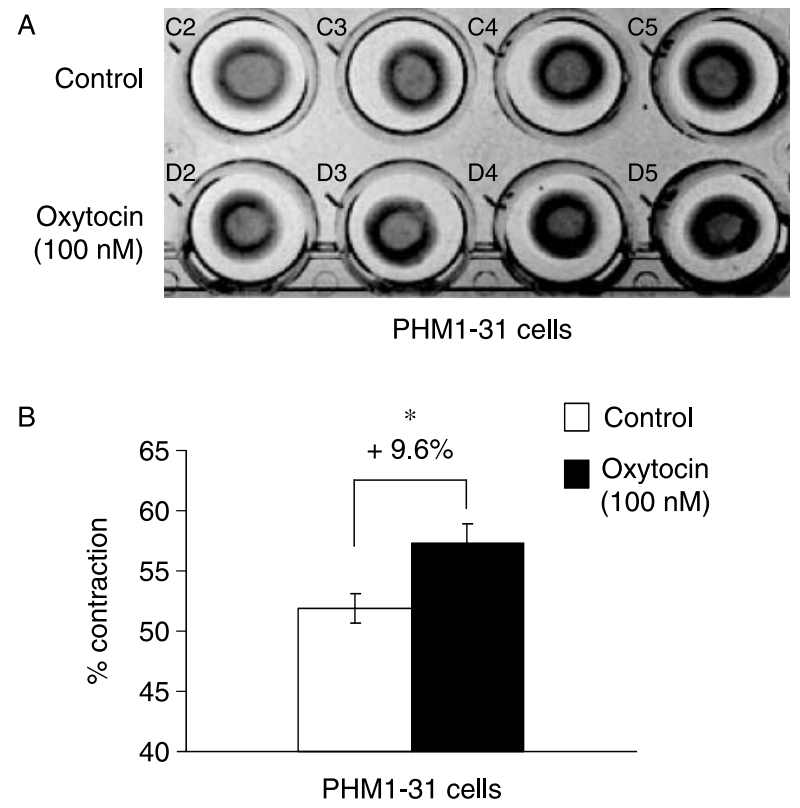

Figure 1 Contractility of PHM1-31 cells. (A) Contractility of PHM1-31 cells in the collagen lattice assay. Lattices were prepared and covered by PHM1-31 cells $\left(2.5 \times 10^{4}\right.$ cells/well) in the absence (control) or presence of oxytocin $(100 \mathrm{nM})$ that induces contraction. Lattices are visible in the centre of each well. Following oxytocin treatment, the surface area of the lattice is about $10 \%$ smaller (i.e., $10 \%$ contraction). (B) Quantification of oxytocin-induced contraction of PHM1-31 cells. Each bar represents the mean \pm S.E.M. of at least quadruplicates. The experiment shown is representative of four independent experiments.
(Devost \& Zingg 2007), PHM1-31 cells exhibit 50\% basal contraction. This contraction is specific to muscle cells since we did not detect any contraction with human embryonic kidney HEK 293 cells (data not shown). Furthermore, we found that treatment with oxytocin $(100 \mathrm{nM})$, a uterotonic agent, led to an additional $10 \%$ increase in the contraction of PHM1-31 cells.

\section{Genechip array analysis of IL-1 $\beta$-treated PHM1-31 cells}

To better understand the effect of IL-1 $\beta$ on smooth muscle cells, we performed genechip expression array analysis. RNA extracted from control PHM1-31 cells and PHM1-31 cells treated with $1 \mathrm{ng} / \mathrm{ml} \mathrm{IL-1} \beta$ for $1 \mathrm{~h}$ was converted into cRNA and then hybridized to a HG-U133_Plus_2 Affymetrix genechip. We performed three independent experiments to obtain statistically significant data. A minus versus average plot and principal component analysis plot were done confirming that the three chips analyzed behaved similarly (data not shown). This quality control step is essential to avoid normalization problems in the data set. We performed a robust multi-array average (RMA) analysis and found a set of 198 genes (186 up-regulated and 12 downregulated genes) showing a $\geq 2.0$-fold change in transcript levels in untreated versus IL-1 $\beta$-treated PHM1-31 cells. These genes are primarily involved in inflammatory response, transcriptional regulation, cell adhesion, and signal transduction.

Table 1 lists all the genes that are induced at least threefold, whereas Table 2 lists all the genes downregulated by IL-1 $\beta$ treatment. A cutoff of twofold has been chosen for the down-regulated genes since we did not detect any genes reduced more than threefold upon IL-1 $\beta$ treatment in PHM1-31 cells. Overall, in our microarray, the number of up-regulated genes by IL-1 $\beta$ is greater than the number of down-regulated genes. This was not unexpected since previous studies in other cell lines have shown a similar pattern (Rossi et al. 2005, Ha et al. 2006). This data could be explained by the fact that IL-1 $\beta$ is an activator of pathways more than a repressor. The heat map in Fig. 2 shows the transcript levels in untreated and IL-1 $\beta$-treated cells for the three independent sets of experiments to underscore the reproducibility of the data.

\section{Analysis of genes modulated by IL-1 $\beta$}

We selected a series of genes identified in the genechip expression array studies for further analysis. To this end, we used several selection criteria: a transcript-level change of at least threefold, a significant basal gene expression level when compared with background level, as well as a possible link between the particular gene and myometrial cell function, gestation, or preterm labor. Using these criteria, we chose to investigate seven 
Table 1 Ninety-eight genes are significantly up-regulated (fold change $>3$ ) in human PHM1-31 myometrial cells after interleukin-1 $\beta$ (IL-1 $\beta$ ) stimulation $(1 \mathrm{ng} / \mathrm{ml})$ for $1 \mathrm{~h}$.

\begin{tabular}{|c|c|c|c|}
\hline Gene symbol & Fold change & Gene ID & Description \\
\hline \multicolumn{4}{|c|}{ Inflammatory response/immune response } \\
\hline TNFAIP3/A20 & 28.73 & 202643_s_at & Tumor necrosis factor, $\alpha$-induced protein 3 \\
\hline CXCL3 & 21.55 & 207850_at & Chemokine (C-X-C motif) ligand 3 \\
\hline SOD2 & 19.21 & 215078_at & Superoxide dismutase 2 , mitochondrial \\
\hline CCL20 & 17.86 & 205476_at & Chemokine (C-C motif) ligand 20 \\
\hline CXCL2 & 15.89 & 209774_x_at & Chemokine (C-X-C motif) ligand 2 \\
\hline LIF & 10.06 & 205266_at & Leukemia inhibitory factor (cholinergic differentiation factor) \\
\hline IL6 & 8.61 & 205207_at & Interleukin 6 (interferon, $\beta 2$ ) \\
\hline PTGS2 & 7.89 & 204748_at & $\begin{array}{l}\text { Prostaglandin-endoperoxide synthase } 2 \text { (prostaglandin G/H synthase and } \\
\text { cyclooxygenase) }\end{array}$ \\
\hline PTX3 & 5.97 & 206157_at & Pentraxin-related gene, rapidly induced by IL-1 $\beta$ \\
\hline CXCL1 & 5.84 & 204470_at & $\begin{array}{l}\text { Chemokine (C-X-C motif) ligand } 1 \text { (melanoma growth-stimulating } \\
\text { activity, } \alpha \text { ) }\end{array}$ \\
\hline CSF3 & 4.20 & 207442_at & Colony-stimulating factor 3 (granulocyte) \\
\hline TNFAIP6 & 3.67 & 206025_s_at & Tumor necrosis factor, $\alpha$-induced protein 6 \\
\hline OLR1 & 3.63 & 242397_at & Oxidised low-density lipoprotein (lectin-like) receptor 1 \\
\hline GEM & 3.12 & 204472_at & GTP-binding protein overexpressed in skeletal muscle \\
\hline GBP2 & 3.06 & 242907_at & Guanylate-binding protein 2, interferon inducible \\
\hline \multicolumn{4}{|c|}{ Cell adhesion/cell motility } \\
\hline TNC & 20.71 & 216005_at & Tenascin C (hexabrachion) \\
\hline IFNAR2 & 11.87 & 230735_at & Interferon $(\alpha, \beta$, and $\omega)$ receptor 2 \\
\hline CLDN1 & 9.14 & 238967_at & Claudin 1 \\
\hline SERPINE2 & 7.54 & 236599_at & $\begin{array}{l}\text { Serpin peptidase inhibitor, clade } \mathrm{E} \text { (nexin, plasminogen activator inhibitor } \\
\text { type } 1 \text { ), member } 2\end{array}$ \\
\hline ICAM1 & 6.44 & 202638_s_at & Intercellular adhesion molecule 1 (CD54), human rhinovirus receptor \\
\hline CSF2 & 6.29 & 210229_s_at & Colony-stimulating factor 2 (granulocyte-macrophage) \\
\hline VCAM1 & 3.11 & 203868_s_at & Vascular cell adhesion molecule 1 \\
\hline \multicolumn{4}{|l|}{ Apoptosis } \\
\hline BIRC3 & 15.04 & 210538_s_at & Baculoviral IAP repeat-containing 3 \\
\hline C11orf17 & 12.33 & 220987_s_at & Chromosome 11 open reading frame 17 \\
\hline NFKBIA & 9.72 & 201502_s_at & Nuclear factor of $\kappa$ light polypeptide gene enhancer in B-cells inhibitor, $\alpha$ \\
\hline IER3 & 6.83 & 201631_s_at & Immediate early response 3 \\
\hline SOCS3 & 6.53 & 227697_at & Suppressor of cytokine signaling 3 \\
\hline TNFAIP8 & 5.37 & 242827_x_at & Tumor necrosis factor, $\alpha$-induced protein 8 \\
\hline AXUD1 & 5.04 & 225557_at & AXIN1 up-regulated 1 \\
\hline SERPINB2 & 4.72 & 204614_at & Serpin peptidase inhibitor, clade B (ovalbumin), member 2 \\
\hline IFNB1 & 3.60 & 208173_at & Interferon, $\beta$ 1, fibroblast \\
\hline PPP1R15A & 3.42 & 202014_at & Protein phosphatase 1 , regulatory (inhibitor) subunit $15 \mathrm{~A}$ \\
\hline TNFAIP8 & 3.29 & 210260_s_at & Tumor necrosis factor, $\alpha$-induced protein 8 \\
\hline \multicolumn{4}{|l|}{ Angiogenesis } \\
\hline IL8 & 7.28 & 211506_s_at & Interleukin 8 \\
\hline NRP2 & 6.88 & 232701_at & Neuropilin 2 \\
\hline TNFAIP2 & 5.60 & 202510_s_at & Tumor necrosis factor, $\alpha$-induced protein 2 \\
\hline RHOB & 3.25 & 212099_at & Ras homolog gene family, member B \\
\hline \multicolumn{4}{|c|}{ DNA repair/regulation of transcription } \\
\hline EGR3 & 20.53 & 206115_at & Early growth response 3 \\
\hline EGR2 & 14.61 & 205249_at & Early growth response 2 (Krox-20 homolog, Drosophila) \\
\hline NFKB1 & 10.89 & 239876_at & Nuclear factor of $\kappa$ light polypeptide gene enhancer in B-cells 1 (p105) \\
\hline TNF & 10.70 & 207113_s_at & Tumor necrosis factor (TNF superfamily, member 2 ) \\
\hline IRF1 & 7.09 & 202531_at & Interferon regulatory factor 1 \\
\hline EGR1 & 6.29 & 201693_s_at & Early growth response 1 \\
\hline JUNB & 5.70 & 201473_at & Jun B proto-oncogene \\
\hline ATF3 & 5.38 & 202672_s_at & Activating transcription factor 3 \\
\hline JUN & 5.29 & 201466_s_at & v-jun sarcoma virus 17 oncogene homolog (avian) \\
\hline NKX3-1 & 5.22 & 209706_at & NK3 transcription factor related, locus 1 (Drosophila) \\
\hline REL & 4.98 & 206036_s_at & v-rel reticuloendotheliosis viral oncogene homolog (avian) \\
\hline NR4A2 & 4.45 & 216248_s_at & Nuclear receptor subfamily 4 , group A, member 2 \\
\hline BTG2 & 4.42 & 201236_s_at & BTG family, member 2 \\
\hline CEBPD & 4.11 & 213006_at & CCAAT/enhancer-binding protein (C/EBP), $\delta$ \\
\hline MSC & 4.03 & 209928_s_at & Musculin (activated B-cell factor-1) \\
\hline NR4A3 & 3.98 & 209959_at & Nuclear receptor subfamily 4, group A, member 3 \\
\hline BHLHB2 & 3.96 & 201170_s_at & Basic helix-loop-helix domain containing, class B, 2 \\
\hline MAFF & 3.65 & 36711_at & v-maf musculoaponeurotic fibrosarcoma oncogene homolog F (avian) \\
\hline NFKBIE & 3.53 & 203927_at & $\begin{array}{l}\text { Nuclear factor of } \kappa \text { light polypeptide gene enhancer in B-cells inhibitor, } \\
\text { epsilon }\end{array}$ \\
\hline
\end{tabular}


Table 1 Continued.

\begin{tabular}{|c|c|c|c|}
\hline Gene symbol & Fold change & Gene ID & Description \\
\hline KLF10 & 3.43 & 202393_s_at & Kruppel-like factor 10 \\
\hline ETS1 & 3.23 & 241435_at & V-ets erythroblastosis virus E26 oncogene homolog 1 (avian) \\
\hline SMURF2 & 3.20 & 241900_at & SMAD-specific E3 ubiquitin protein ligase 2 \\
\hline NFKB2 & 3.02 & 207535_s_at & $\begin{array}{l}\text { Nuclear factor of } \kappa \text { light polypeptide gene enhancer in B-cells } 2 \\
(\mathrm{p} 49 / \mathrm{p} 100)\end{array}$ \\
\hline \multicolumn{4}{|r|}{ (1) } \\
\hline RASD1 & 5.79 & 223467_at & RAS, dexamethasone-induced 1 \\
\hline DUSP2 & 5.67 & 204794_at & Dual specificity phosphatase 2 \\
\hline PBEF1 & 5.42 & 243296_at & Pre-B-cell colony-enhancing factor 1 \\
\hline HBEGF & 4.17 & 203821_at & Heparin-binding EGF-like growth factor \\
\hline DSCR1 & 3.86 & 208370_s_at & Down syndrome critical region gene 1 \\
\hline CD69 & 3.44 & 209795_at & CD69 molecule \\
\hline EDN1 & 3.40 & 222802_at & Endothelin 1 \\
\hline CD83 & 3.27 & 204440_at & CD83 molecule \\
\hline TRAF1 & 3.26 & 205599_at & TNF receptor-associated factor 1 \\
\hline \multicolumn{4}{|l|}{ Transport } \\
\hline SLC39A14 & 6.23 & 1561886_a_at & Solute carrier family 39 (zinc transporter), member 14 \\
\hline \multicolumn{4}{|c|}{ mRNA catabolism } \\
\hline ZFP36 & 7.02 & 201531_at & Zinc finger protein $36, \mathrm{C} 3 \mathrm{H}$ type, homolog (mouse) \\
\hline \multicolumn{4}{|c|}{ Regulation of translation } \\
\hline SAMD4A & 6.68 & 230503_at & Sterile $\alpha$ motif domain containing $4 \mathrm{~A}$ \\
\hline \multicolumn{4}{|c|}{ Protein amino acid phosphorylation } \\
\hline MAP3K8 & 14.06 & 205027_s_at & MAP kinase kinase kinase 8 \\
\hline DUSP1 & 7.30 & 201041_s_at & Dual specificity phosphatase 1 \\
\hline EGFR & 4.92 & 232925_at & $\begin{array}{l}\text { Epidermal growth factor receptor (erythroblastic leukemia viral (v-erb-b) } \\
\text { oncogene homolog, avian) }\end{array}$ \\
\hline PIM3 & 4.58 & 224739_at & Pim-3 oncogene \\
\hline IRAK2 & 4.27 & 231779_at & Interleukin-1 receptor-associated kinase 2 \\
\hline DUSP5 & 3.59 & 209457_at & Dual specificity phosphatase 5 \\
\hline CCL2 & 3.41 & 216598_s_at & Chemokine (C-C motif) ligand 2 \\
\hline PTPN1 & 3.30 & 240260_at & Protein tyrosine phosphatase, non-receptor type 1 \\
\hline \multicolumn{4}{|l|}{ Proteolysis } \\
\hline PAPPÁ & 3.63 & 232748_at & Pregnancy-associated plasma protein A, pappalysin 1 \\
\hline CRIM1 & 3.04 & 233073_at & Cysteine-rich transmembrane BMP regulator 1 (chordin-like) \\
\hline \multicolumn{4}{|l|}{ Other } \\
\hline NFKBIZ & 13.41 & 223217_s_at & Nuclear factor of $\kappa$ light polypeptide gene enhancer in B-cells inhibitor, $\zeta$ \\
\hline $\mathrm{ZC} 3 \mathrm{H} 12 \mathrm{~A}$ & 8.90 & 218810_at & Zinc finger $\mathrm{CCCH}$-type containing $12 \mathrm{~A}$ \\
\hline WTAP & 6.56 & 244219_at & Wilms tumor 1 -associated protein \\
\hline C20orf175 & 5.47 & 240410_at & Chromosome 20 open reading frame 175 \\
\hline TA-NFKBH & 5.43 & 230052_s_at & T-cell activation NFKB-like protein \\
\hline TJP2 & 5.24 & 1565863_at & Tight junction protein 2 (zona occludens 2) \\
\hline FAM43A & 4.90 & 227410_at & Family with sequence similarity 43 , member $A$ \\
\hline SAT & 4.84 & 230333_at & Spermidine/spermine N1-acetyltransferase \\
\hline PRG1 & 4.77 & 1554676_at & Proteoglycan 1 , secretory granule \\
\hline TJP2 & 4.18 & 232017_at & Tight junction protein 2 (zona occludens 2) \\
\hline IER2 & 3.89 & 202081_at & Immediate early response 2 \\
\hline JMJD3 & 3.87 & 213146_at & Jumonji domain containing 3 \\
\hline $\mathrm{COL} 4 \mathrm{~A} 2$ & 3.50 & 237624_at & Collagen, type IV, $\alpha 2$ \\
\hline G0S2 & 3.31 & 213524_s_at & G0/G1switch 2 \\
\hline $\mathrm{GCH} 1$ & 3.03 & 204224_s_at & GTP cyclohydrolase 1 (dopa-responsive dystonia) \\
\hline PPP1R15B & 3.00 & 224692_at & Protein phosphatase 1 , regulatory (inhibitor) subunit $15 B$ \\
\hline
\end{tabular}

genes indicated in bold in Table 1: chemokine C-X-C motif ligand 3 (CXCL3), pentraxin-related gene (PTX3), tenascin C (TNC), TNF $\alpha$-induced protein 3/A20 (TNFAIP3/A20), p105 subunit of the nuclear factor of $\kappa$ light polypeptide gene enhancer in B-cells (NFKB1), v-maf musculoaponeurotic fibrosarcoma oncogene homolog $\mathrm{F}$ (MAFF), and plasminogen activator urokinase (PLAU). We confirmed by Northern blot experiments the expression-level changes observed for CXCL3, PTX3, TNC, and PLAU in the microarray studies for $1 \mathrm{~h}$ of $1 \mathrm{ng} / \mathrm{ml}$ IL-1 $\beta$ treatment (Fig. 3A). We also performed a time course experiment with $1 \mathrm{ng} / \mathrm{ml}$ of $\mathrm{IL}-1 \beta$ for $0.5-24 \mathrm{~h}$. For all the genes studied, we observed an increase in mRNA levels $24 \mathrm{~h}$ after the initial IL-1 $\beta$ treatment with an induction peak at $3 \mathrm{~h}$ for the PTX3 gene, at $8 \mathrm{~h}$ for the CXCL3 and PLAU genes, and at $24 \mathrm{~h}$ 
Table 2 Twelve genes are significantly down-regulated (fold change down $>2$ ) in human PHM1-31 myometrial cells after interleukin-1 $\beta$ (IL-1 $\beta$ ) stimulation $(1 \mathrm{ng} / \mathrm{ml})$ for $1 \mathrm{~h}$.

\begin{tabular}{|c|c|c|c|}
\hline Gene symbol & Fold change & Gene ID & Description \\
\hline \multicolumn{4}{|l|}{ Cell adhesion } \\
\hline LAMB1 & 0.34 & 238608_at & Laminin, $\beta 1$ \\
\hline ARHGAP5 & 0.48 & 242110_at & Rho GTPase-activating protein 5 \\
\hline LAMA4 & 0.40 & 1556935_at & Laminin, $\alpha 4$ \\
\hline \multicolumn{4}{|c|}{ Regulation of transcription } \\
\hline ID1 & 0.41 & 208937_s_at & Inhibitor of DNA binding 1, dominant negative helix-loop-helix protein \\
\hline YEATS2 & 0.41 & 236462_at & YEATS domain containing 2 \\
\hline \multicolumn{4}{|l|}{ Transport } \\
\hline SLC16A4 & 0.48 & 228455_at & Solute carrier family 16 (monocarboxylic acid transporters), member 4 \\
\hline \multicolumn{4}{|c|}{ Electron transport } \\
\hline DKK3 & 0.43 & 232947_at & Dickkopf homolog 3 (Xenopus laevis) \\
\hline \multicolumn{4}{|l|}{ Cell cycle } \\
\hline RGS2 & 0.42 & 202388_at & Regulator of G-protein signaling 2, $24 \mathrm{kDa}$ \\
\hline \multicolumn{4}{|l|}{ Stress response } \\
\hline GSTA4 & 0.47 & 235405_at & Glutathione $S$-transferase A4 \\
\hline \multicolumn{4}{|l|}{ Other } \\
\hline FBXL11 & 0.49 & 215191_at & F-box and leucine-rich repeat protein 11 \\
\hline HPS3 & 0.49 & 241036_at & Hermansky-Pudlak syndrome 3 \\
\hline ZFP64 & 0.40 & 242759_at & Zinc finger protein 64 homolog (mouse) \\
\hline
\end{tabular}

for the TNC gene (Fig. 3). For CXCL3, the induction is rapid since it is observed $30 \mathrm{~min}$ after IL-1 $\beta$ exposure of PHM1-31 cells (Fig. 3A).

By immunoblot analysis, we observed an induction of NFKB p50 protein as early as 30 min after IL-1 $\beta$ stimulation of PHM1-31 cells (Fig. 4A). This induction is maintained $24 \mathrm{~h}$ following IL-1 $\beta$ treatment. We also studied TNFAIP3/A20, a target gene of NFKB (Krikos et al. 1992). After 30 min of IL-1 $\beta$ exposure, TNFAIP3/ A20 protein level is already induced and this induction is gradually increased until $24 \mathrm{~h}$ (Fig. 4A).

We also analyzed MAFF, a transcription factor belonging to the basic leucine zipper family. Previously, we showed that MAFF mRNA levels are induced within 30 min with IL-1 $\beta$ in PHM1-31 cells (Massrieh et al. 2006). In this study, we confirmed that this induction also occurs rapidly at the protein level (Fig. 4B). MAFF proteinlevel induction persists $24 \mathrm{~h}$ following IL-1 $\beta$ stimulation.

\section{Discussion}

In this report, we analyzed the response of PHM1-31 myometrial cells to the proinflammatory cytokine IL- $1 \beta$. We and others have previously characterized PHM1-31 uterine smooth muscle cells (Monga et al. 1996, Madsen et al. 2004, Massrieh et al. 2006). Their morphology is highly similar to that of regular proliferating uterine smooth muscle cells as they are long and spindle shaped with a central nucleus. Using an in vitro collagen latticebased assay (Wilson et al. 2001), we showed that PHM1-31 cells are able to contract in the absence of an inducing agent (Fig. 1). Upon stimulation of PHM1-31 cells with oxytocin, a posterior pituitary hormone, we observed an additional $10 \%$ increase of contraction. Oxytocin has been shown to promote contraction during parturition and is widely used as a uterotonic agent (Gimpl \& Fahrenholz 2001). Our novel data further establish PHM1-31 cells as a suitable model to dissect uterine smooth muscle cell function.

Previously, various functional genomic approaches have been used to identify events occurring during the parturition process. These studies examined rodent or human models, comparing the gene expression profiles before and after the onset of labor (Girotti \& Zingg 2003, Havelock et al. 2005) in laboring and non-laboring myometrium specimens (Aguan et al. 2000, Bethin et al. 2003, Girotti \& Zingg 2003) and in preterm and term myometrium samples (Charpigny et al. 2003, Girotti \& Zingg 2003).

It is well established that cytokines are involved in the events leading to preterm labor with intrauterine infection (Hirsch et al. 2006, Sadowsky et al. 2006). Thus, using a genechip array approach, we identified a large number of IL-1 $\beta$ responsive genes in human PHM1-31 myometrial cells suggesting a complex cellular response to cytokine stimulation (Tables 1 and 2). The predominant changes in gene expression are those associated with inflammatory and/or immune response ( $\approx 15 \%$ of the induced genes). This observation corroborates previous microarray studies showing an important role of the inflammatory response in the uterus during labor (Girotti \& Zingg 2003, Havelock et al. 2005). Among the inflammatory response genes, we identified PTX3 (or TNFAIP5) as a gene up-regulated by IL-1 $\beta$. PTX3 has been initially identified as an IL-1 $\beta$-inducible gene in endothelial cells (Breviario et al. 1992). It has been demonstrated recently that PTX3 expression is 


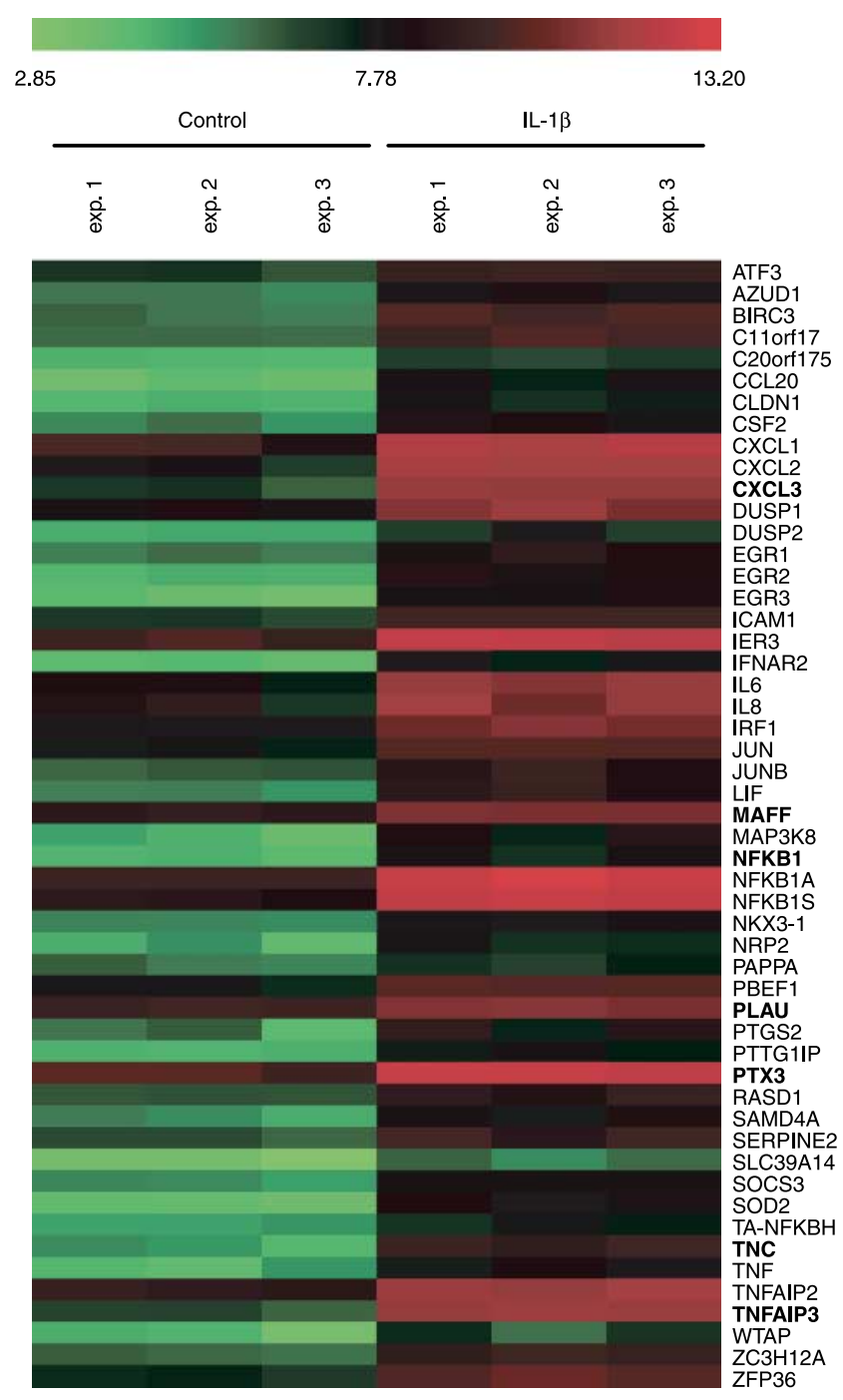

Figure 2 Heat map for genes up-regulated (fold change $>5$ ) and selected for further studies (in bold) in human PHM1-31 myometrial cells after IL-1 $\beta(1 \mathrm{ng} / \mathrm{ml})$ stimulation for $1 \mathrm{~h}$.

higher in the maternal plasma of women with preterm delivery compared with women delivering at term (Assi et al. 2007). Hence, our data may add support to the speculation that PTX3 is implicated in the labor process in uterine smooth muscle cells, in particular during an inflammatory response.

We also identified TNFAIP3/A20 as an inflammatory response gene strongly induced by IL-1 $\beta$ in PHM1-31 cells. It is well established that TNFAIP3/A20 is an $\mathrm{NF \kappa B}$ target gene (Krikos et al. 1992). More recently, it has been shown that TNFAIP3/A20 blocks NFKB signaling via a negative feedback loop (Wertz et al. 2004). We found that TNFAIP3/A20 transcript and protein levels are rapidly induced in PHM1-31 cells by $30 \mathrm{~min}$ and its expression is kept at a high level for at least $24 \mathrm{~h}$. Previously, it has been reported that the binding of the general transcriptional machinery and particularly the transcription factor specificity protein 1 (Sp1) to the TNFAIP3/A20 promoter is essential for a rapid induction of this gene through the NFKB pathway in response to TNFa (Ainbinder et al. 2002). We hypothesize that a similar mechanism occurs in myometrial cells to regulate TNFAIP3/A20. This is of interest as NFKB has been shown to a play a major role in cytokine signaling in uterine smooth muscle cells (Zaragoza et al. 2006) and possibly in parturition (Condon et al. 2005). Indeed, many inflammatory response genes such as TNFAIP3/A20, superoxide dismutase 2 (SOD2), IL6, and leukemia inhibitory factor (LIF) have been demonstrated to be NFKB-dependent (Xu et al. 1999, Legrand-Poels et al. 2000, Ainbinder et al. 2002, Fan et al. 2004).

In addition to NFKB protein, the MAFF transcription factor, a member of the Maf family of basic leucine zipper transcription factors, may be of particular interest for IL-1 $\beta$ response in myometrial cells. We confirmed data of our earlier study with respect to the induction of the MAFF by IL-1 $\beta$ (Fig. 2 and Table 1; Massrieh et al. 2006). Originally, human MAFF had been identified in a one-hybrid assay as a factor binding to regulatory sequences of the oxytocin receptor gene (Kimura et al. 1999). Interestingly, MAFF is highly expressed in term myometrium but is not present in early gestation (14 weeks) and nonpregnant myometrial tissue (Kimura et al. 1999, Bethin et al. 2003). In accordance with earlier data (Massrieh et al. 2006), we also showed in our microarray studies that the transcript levels of the highly homologous MAFG and MAFK genes are not significantly altered (1.16- and 1.19-fold changes respectively) in $1 \mathrm{~h}$ following IL-1 $\beta$ treatment (data not shown). Our results suggest that MAFF, but not MAFG and MAFK, may function as a transcriptional mediator of the early inflammatory response in myometrial cells.

Cytokine stimulation of PHM1-31 cells also results in an increased chemotaxis as shown, for example, by induction of CXCL3 gene expression. Chemotaxis could be defined as a cellular response leading to migration and activation of monocytes and macrophages in the site of inflammation. In this process, chemotactic cytokines, also called chemokines, play a major role and are considered as secondary pro-inflammatory mediators (Dimitriadis et al. 2005). Thus, elevated mRNA level of CXCL3, a gene encoding a small cytokine belonging to the CXC chemokine family, in PHM1-31 cells $1 \mathrm{~h}$ following IL-1 $\beta$ treatment can be considered as an early indicator of inflammatory response in those cells. Other chemokines (listed in Tables 1 and 2 in the inflammatory response section) are also significantly induced by IL-1 $\beta$ clearly establishing the myometrium as a tissue mediating a strong inflammatory response.

We have also noted that IL-1 $\beta$ treatment enhances expression of several ECM remodeling enzymes such as TNC and PLAU. It has been shown that TNC, an ECM glycoprotein, is up-regulated in the myometrium of pregnant rabbits compared with non-pregnant 
A

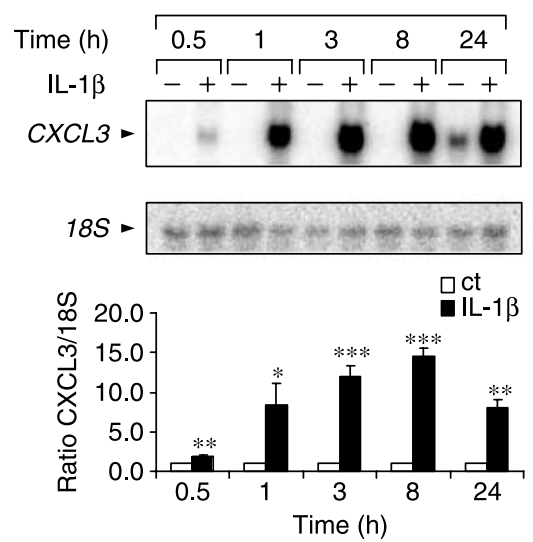

C
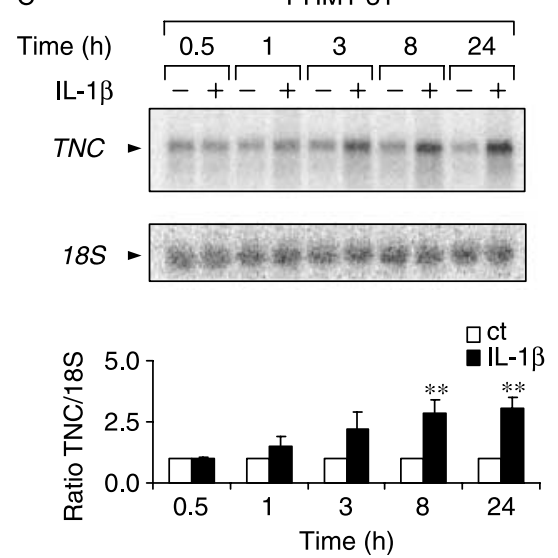

B
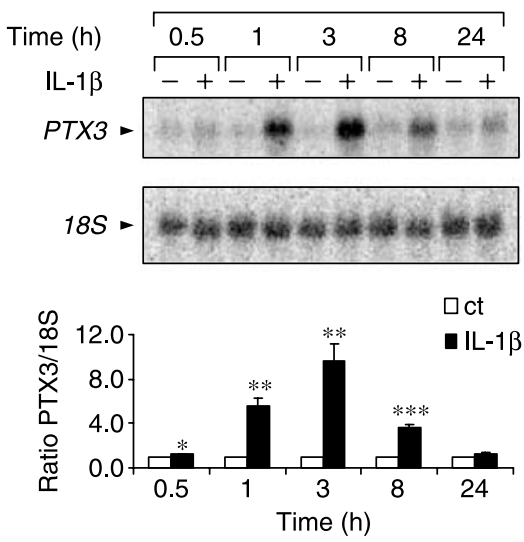

D
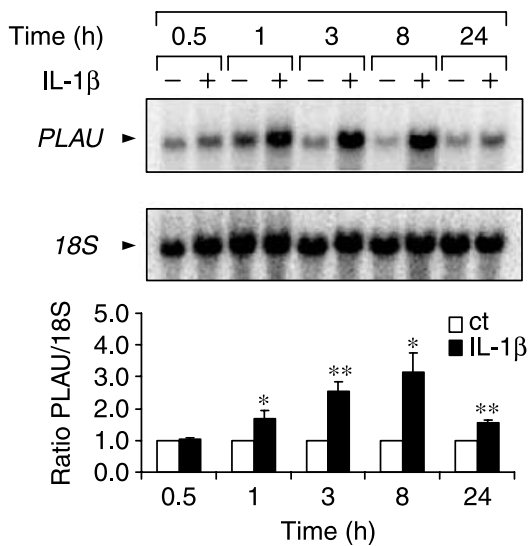

Figure 3 Human (A) CXCL3, (B) PTX3, (C) TNC, and (D) PLAU mRNA levels in PHM1-31 cells treated with $1 \mathrm{ng} / \mathrm{ml} \mathrm{IL}-1 \beta$ for $0.5,1,3,8$, and $24 \mathrm{~h}$. Ten micrograms of total RNA per lane were loaded. Signal levels were quantified, standardized with $18 \mathrm{~S}$ mRNA level, and expressed as relative to time-matched controls. Figures are representative of at least three independent experiments. ${ }^{*} P<0.05 ;{ }^{* *} P<0.01 ;{ }^{* * *} P<0.001$ compared with time-matched controls. myometrium (Cario-Toumaniantz et al. 2003). Nevertheless, further experiments are required to uncover the role of TNC as well as the function of PLAU in myometrial cells and particularly during preterm labor.

Uterine activation results from the coordinated expression of a cassette of contraction-associated proteins including oxytocin receptor, connexin-43, and prostaglandin receptors (Cook et al. 2000). Prostaglandins play a major role in preterm and term labor, particularly in response to cytokines (Mitchell et al. 1993, Keelan et al. 2003, Park et al. 2005). It is well established that IL-1 $\beta$ is a major activator of the crucial and rate-determining enzyme in prostaglandin biosynthesis (PTGS2, also called COX-2; Rauk \& Chiao 2000).

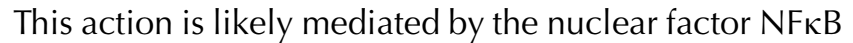
(Ackerman et al. 2004, Soloff et al. 2004). In agreement with these data, expression of PTGS2 and NFKB genes is strongly induced by IL-1 $\beta$ (7.9- and 10.9-fold increase for PTGS2 and NFKB respectively).

Based on our data, we propose a novel hypothetical model of IL-1 $\beta$ signaling in myometrial cells as depicted in Fig. 5. In PHM1-31 cells, IL-1 $\beta$ induces an inflammatory and immune response and increases the expression of key transcription factors like $\mathrm{NF \kappa B}$.
Consequently, chemotaxis and synthesis of prostaglandins occur. In parallel, IL-1 $\beta$ increases the expression of the ECM remodeling enzymes. Our genechip data indicate that $1 \mathrm{~h}$ exposure of $\mathrm{IL}-1 \beta$ has no effect on gene expression of key molecules required for contraction (i.e., oxytocin receptor and connexin 43) in PHM1-31 cells (data not shown). Hence, we hypothesize that PHM1-31 cells exposed to IL-1 $\beta$ for $1 \mathrm{~h}$ are in an intermediate phase between the quiescent state and an activated state leading to uterine activation. Interestingly, it has recently been demonstrated that preterm labor in monkeys can be provoked through an intraamniotic infusion of IL-1 $\beta$ or TNF $\alpha$ (Sadowsky et al. 2006). In addition, it has been recently shown that absence of both IL-1 $\beta$ and TNF $\alpha$ in knockout mice clearly delays labor (Hirsch et al. 2006). Hence, the action of multiple cytokines may be required to convert myometrial cells into a fully contractile state. In agreement with these data, we observed a significant induction of interleukins IL6 (8.6-fold induction; Schmid et al. 2001) and IL8 (7.3-fold induction; Arntzen et al. 1998) mRNA levels in response to IL-1 $\beta$. In addition, it has been demonstrated that PHM1-31 cells retain the ability to respond to oxytocin and thapsigargin with an 
A

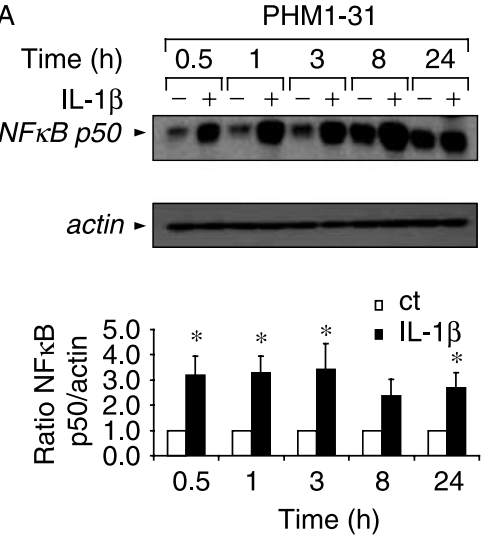

B

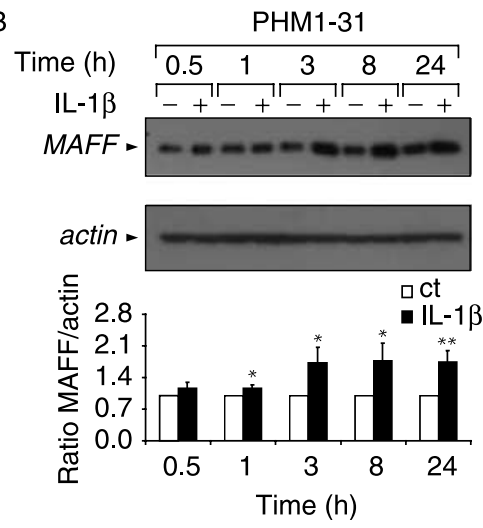

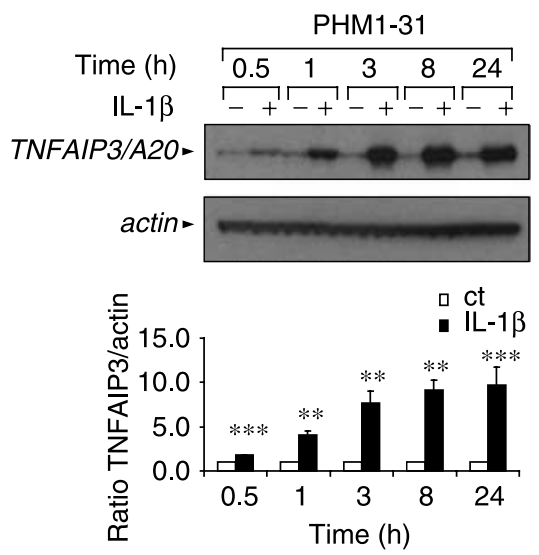

Figure 4 Human NFKB p50 and TNFAIP3/A20 (A) and MAFF (B) protein levels in PHM1-31 cells treated with $1 \mathrm{ng} / \mathrm{ml} \mathrm{IL-} 1 \beta$ for $0.5,1,3,8$, and $24 \mathrm{~h}$. Thirty micrograms of nuclear (for NFKB p50 and MAFF) or whole cell extracts (for TNFAIP3/A20) were loaded per well. Signal levels were quantified, standardized with actin protein level, and expressed as relative to time-matched controls. Figures are representative of at least three independent experiments. ${ }^{*} P<0.05 ;{ }^{* *} P<0.01$; $* * * P<0.001$ compared with time-matched controls. increase in intracellular calcium (Shlykov et al. 2003). Nevertheless, PHM1-31 cells appear to lack significant L-type $\mathrm{Ca}^{2+}$ channel expression, which suggest that the entry of $\mathrm{Ca}^{2+}$ into the cells may be through a passive leak or another mechanism to be elucidated (Sanborn 2001, Shlykov et al. 2003). Moreover, the role of calcium mobilization in the contraction of myometrium remains to be clarified. In this respect, it has been previously demonstrated that the sarcoplasmic reticulum calcium ATPase $2 \mathrm{~b}$ (SERCA) is increased in primary-cultured human myometrial smooth muscle cells exposed to IL-1 $\beta$ for $24 \mathrm{~h}$ (Tribe et al. 2003). We did not observe any change in SERCA gene transcript levels (data not shown), probably due to the early timepoint examined.

In summary, this study and our previous data (Massrieh et al. 2006) underline the importance of cytokine signaling in uterine smooth muscle cells (Fig. 5). This is of interest because cytokine production is highly induced after bacterial infection of the choriodecidual space (Zaga et al. 2004). Our results validate the myometrium as a strong inflammatory response tissue. Combined with previous published studies, our results reiterate the notion that parturition is a complex and concerted process associated with both temporal and spatial expression changes. Hence, our studies provide the basis for further studies into the mechanisms leading to infection-induced preterm labor.

\section{Materials and Methods \\ Cells and culture conditions}

PHM1-31 myometrial cells (provided by Dr Barbara Sanborn (Monga et al. 1996, Madsen et al. 2004)) were cultured at $37^{\circ} \mathrm{C}$ in high-glucose DMEM containing $0.1 \mathrm{mg} / \mathrm{ml}$ geneticin, $10 \%$ fetal calf serum (heat inactivated at $57^{\circ} \mathrm{C}$ ), $2 \mathrm{mM} \mathrm{L-}$ glutamine, $50 \mathrm{U} / \mathrm{ml}$ penicillin, and $50 \mu \mathrm{g} / \mathrm{ml}$ streptomycin. Cytokine induction experiments were performed with cells up to passage 24 reaching $80-90 \%$ confluency. Both control and IL-1 $\beta$-treated cells were fetal bovine serum (FBS) starved for $16-24 \mathrm{~h}$ and then treated for $0.5-24 \mathrm{~h}$ with vehicle $\left(\mathrm{H}_{2} \mathrm{O}\right)$ or with $1 \mathrm{ng} / \mathrm{ml}$ human recombinant IL-1 $\beta$ (Research Diagnostics Inc., Concord, MA, USA) in the absence of serum.

\section{Contraction assay}

The collagen lattice-based retraction assay was performed as described previously (Devost \& Zingg 2007). Shortly, collagen type 1 was prepared from rat tail and resuspended overnight in 


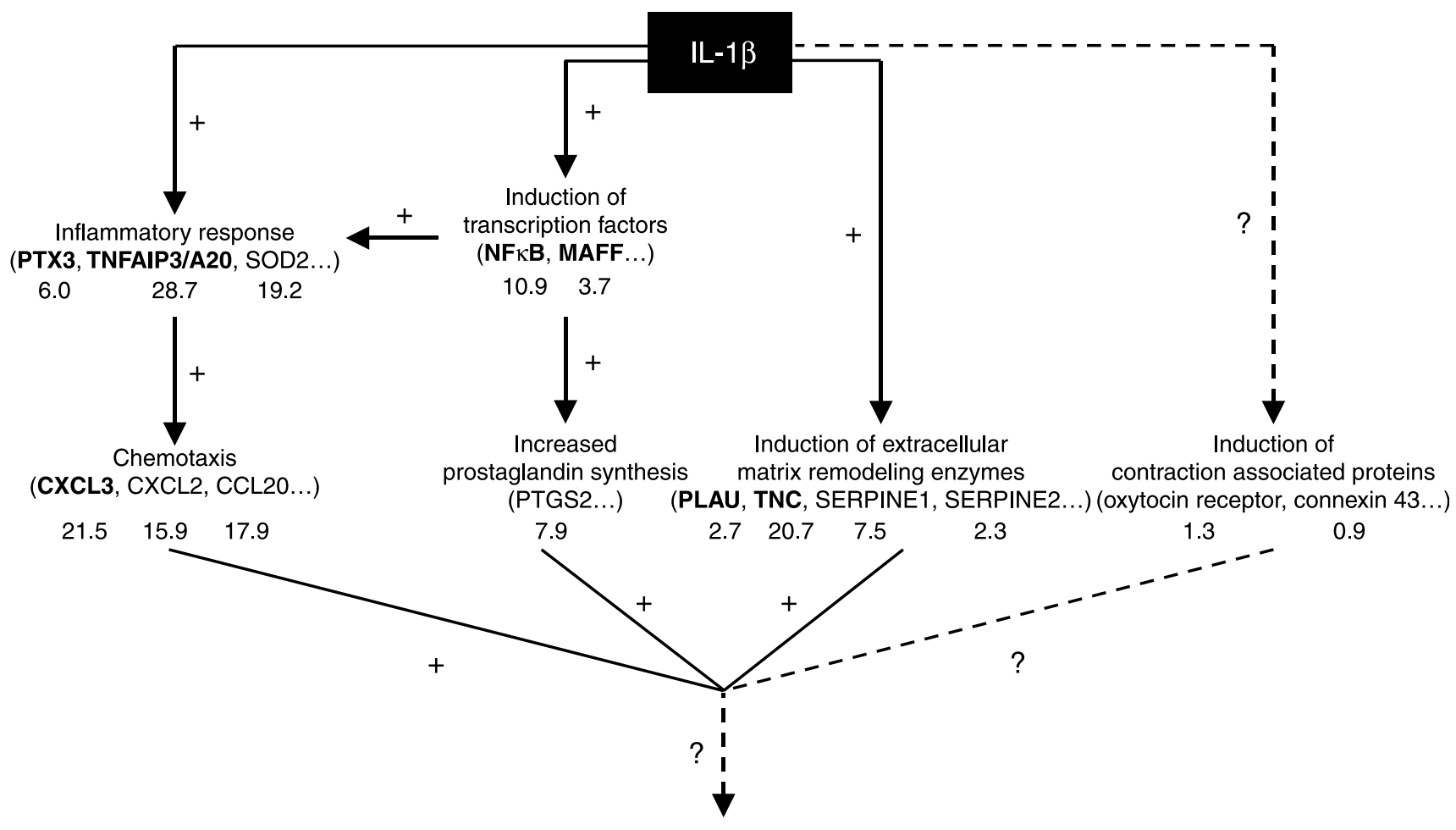

Myometrial cell activity

Figure 5 Hypothetical and simplified model of biochemical pathways involved in IL-1 $\beta$ response of myometrial cells. The number below each gene represents the fold induction obtained in our array experiment of PHM1-31 cells in response to IL-1 $\beta$ stimulation. Genes confirmed by Northern and/or immunoblotting experiments are depicted in bold. Dashed lines denote an absence of IL-1 $\beta$ effect on this pathway.

$0.01 \mathrm{M} \mathrm{HCl}$ to prepare a $5 \mathrm{mg} / \mathrm{ml}$ stock solution and kept at $4{ }^{\circ} \mathrm{C}$ until use. To maintain the $\mathrm{pH}$ between 7.0 and 7.5 , $5 \times$ PBS and $0.1 \mathrm{M} \mathrm{NaOH}$ were added and the preparation was subsequently diluted to $1.5 \mathrm{mg} / \mathrm{ml}$ with DMEM/F-12 supplemented with $0.5 \%$ FBS. Ice-cold collagen solution $(0.5 \mathrm{ml})$ was added to individual wells of a 24 -well plate and incubated at $37^{\circ} \mathrm{C}$ for $1 \mathrm{~h}$ to allow gelling of the collagen. The collagen lattice was then covered with $1 \mathrm{ml}$ DMEM/ F-12 medium supplemented with $0.5 \%$ FBS containing $2.5 \times 10^{4} \mathrm{PHM} 1-31$ myometrial cells. The cells were left to settle for $2 \mathrm{~h}$ at $37^{\circ} \mathrm{C}$. The collagen lattice was detached from the bottom of the well with a spatula, and left overnight at $37{ }^{\circ} \mathrm{C}$ in the absence or presence of $100 \mathrm{nM}$ oxytocin (Sigma). The lattices were fixed overnight at $4{ }^{\circ} \mathrm{C}$ by adding $1 \mathrm{ml} 8 \%$ $(\mathrm{w} / \mathrm{v})$ paraformaldehyde in $\mathrm{PBS}$ at $\mathrm{pH} 7.4$ to stop the contraction and were stored at $4{ }^{\circ} \mathrm{C}$ until analysis. To quantify the surface area of the lattices, the liquid of each well was aspirated and the plate was photographed using the Alpha Innotech Imaging System (Alpha Innotech, San Leandro, CA, USA) with an Olympus C-5060 digital camera. The surface area was quantified using the AlphaEase 5.5 densitometry program (Alpha Innotech). The contraction assay was done at least in quadruplicates and the data were expressed as percentage contraction. Percentage contraction was taken as the percentage of lattice size diminution relative to the size area of the well. The contraction assay was repeated in four independent experiments.

\section{Genechip expression array analysis}

Total RNA from untreated PHM1 cells and PHM1-31 cells treated with IL-1 $\beta$ for $1 \mathrm{~h}$ was prepared using Trizol reagent (Invitrogen). The quality of the purified RNA was verified using an Agilent 2100 Bioanalyzer (Agilent Technologies, Palo Alto, CA, USA). Probe synthesis, hybridization, and scanning were done according to standard Affymetrix protocol. The detailed protocol is available on the following website: http://www. affymetrix.com/support/technical/manual/expression_manual. affx. The microarray used was a HG-U133_Plus_2 genechip expression array (Affymetrix, Santa Clara, CA, USA) covering $\sim 38500$ genes of the human genome. The microarray analysis was repeated in three independent experiments.

\section{Microarray analysis}

Robust multi-array average (RMA) analysis was used to analyze the microarray data. It involves three steps: a model-based background correction, quantile normalization at the probe level, and median polish to produce a robust average of probe intensities for expression summary. Intensity values in log (base 2) scale were then converted into fold change, allowing the identification of differentially expressed genes in control and IL-1 $\beta$-treated cells.

A heat map was generated with the TIGR MultiExperiment Viewer (MeV 4.0) software (http://www.tm4.org/mev.html). 


\section{Northern blot hybridization}

Total RNA was extracted using the Trizol reagent (Invitrogen) according to the manufacturer's instructions. RNA was quantified using standard spectrophotometry. Ten micrograms of RNA were denatured, subjected to electrophoresis on a $1 \%$ $(\mathrm{w} / \mathrm{v})$ agarose gel containing $6 \%(\mathrm{v} / \mathrm{v})$ formaldehyde, transferred overnight onto a HYBOND-XL nylon membrane (Amersham Biosciences), fixed by u.v. cross-linking, and was hybridized (Church \& Gilbert 1984) with ${ }^{32}$ P-labeled probes. The cDNA probes were prepared from PHMI-31 total RNA by a standard RT-PCR procedure. Forward and reverse PCR primers used to generate cDNA probes were as follows (GenBank accession numbers are provided in parentheses): CXCL3 (BC065743), 5'-GCAGGGAATTCACCTCAAGA-3' and 5'-GGTGCTCCCCTTGTTCAGTA-3'; TNC (NM_002160), 5'-AGAGAACCAGCCAGTGGTGT-3' and 5'-GCCTGCTCCTGCAGTACATT3'; PLAU (BC013575), 5'-TCACCACCAAAATGCTGTGT-3' and 5'-AGGCCATTCTCTTCCTTGGT-3'; PTX3 (BC039733), 5'-TGCGATTCTGTTTTGTGCTC-3' and 5'-TGAAGAGCTTGTCCCATTCC $-3^{\prime}$.

To generate the TNFAIP3/A20 probe, a HindIII digestion of the FLAG-A20 plasmid, kindly provided by Dr R. Lin (Lady Davis Institute for Medical Research, Montreal, Canada), was performed and the resulting $340 \mathrm{bp}$ fragment was used for labeling (Lin et al. 2006). The cDNA fragments were radiolabeled with $\left[\alpha^{32} \mathrm{P}\right] \mathrm{dCTP}$ by random priming according to the instructions of the manufacturer (Roche). Hybridization and washes were performed using standard procedures. Membranes were exposed to a phosphorscreen and analyzed by PhosphorImager (Molecular Dynamics, Sunnyvale, CA, USA).

\section{Immunoblot analysis}

Whole cell extracts were prepared by scraping the PHM1-31 cells using $1 \times$ PBS followed by centrifugation. The pellets were then resuspended in lysis buffer $(250 \mathrm{mM}$ sucrose, $420 \mathrm{mM} \mathrm{NaCl}, 10 \mathrm{mM}$ Tris/ $\mathrm{HCl}, 2 \mathrm{mM} \mathrm{MgCl}$, $1 \mathrm{mM} \mathrm{CaCl}$, $1 \%(\mathrm{v} / \mathrm{v})$ Triton $\mathrm{X}-100)$ containing protease inhibitors (Roche) supplemented with $0.5 \mathrm{mM}$ dithiothreitol and $0.2 \mathrm{mM}$ phenylmethylsulphonyl fluoride. After $10 \mathrm{~min}$ swelling on ice, samples were briefly centrifuged, and the supernatant was collected. Protein concentrations were determined using a protein assay kit (Bio-Rad). Thirty micrograms of the lysate were loaded on a gel and electrophoresed in NuPAGE 4-12\% Bis-Tris gels (Invitrogen). Resolved proteins were transferred electrophoretically to a polyvinylidene difluoride membrane (Millipore, Billerica, MA, USA). After membrane saturation at room temperature for $1 \mathrm{~h}$ with TBS $(0.1 \mathrm{M}$ Tris- $\mathrm{HCl}(\mathrm{pH} 8.0)$, $0.15 \mathrm{M} \mathrm{NaCl})$ containing $0.05 \%(\mathrm{v} / \mathrm{v})$ Tween 20 and $5 \%(\mathrm{v} / \mathrm{v})$ milk, the blots were incubated in the same solution overnight with antibodies specific for either human actin (1:10 000; Sigma, \#A-5441), human TNFAIP3/A20 (5 $\mu \mathrm{g} / \mathrm{ml}$; ab13597; Abcam, Cambridge, MA, USA), human NFKB p50 (1:400; sc7178; Santa Cruz Biotechnology, Santa Cruz, CA, USA), or human MAFF (1:5000; Massrieh et al. 2006). After two washes in TBS containing $0.05 \%(\mathrm{v} / \mathrm{v})$ Tween 20 , primary antibody was detected using 1-h incubation with secondary HRP-conjugated antibodies. A goat anti-mouse antibody (1:30 000; 31430;
Pierce, Rockford, IL, USA) was used for actin and TNFAIP3/A20 detection and a goat anti-rabbit antibody (1:30 000; 31 460; Pierce) for NFKB and MAFF detection. Subsequently, the proteins were visualized by exposure to X-ray films (Kodak) using Immobilon Western (Millipore) as a source of chemiluminescent HRP substrate. Membranes were stripped for $15 \mathrm{~min}$ at room temperature in Restore buffer (Pierce) and washed four times in TBS before a new hybridization was performed.

\section{Quantification and statistical analysis}

Quantification of Northern blot experiments was performed using Phosphorlmager and Image Quant software (version 5.2; Molecular Dynamics). Immunoblots were quantified by densitometry using Genetools software (Syngene, Frederick, $M D, U S A)$. The results represent a mean \pm s.E.M. of at least three independent experiments. To evaluate the significance of differences among means, a Student's $t$-test was performed $\left({ }^{*} P<0.05,{ }^{*} P<0.01,{ }^{* * *} P<0.001\right)$.

\section{Acknowledgements}

We would like to thank Barbara Sanborn and Chun-Ying Ku for providing the PHM1-31 cells, and Zaynab Nouhi, Jadwiga Gasiorek, Lucie Carrière, and Florence Doualla-Bell for helpful discussions and reading of the manuscript. We are grateful to Andre Ponton for help with genechip array analysis and to Rongtuan Lin for the gift of FLAG-TNFAIP3 plasmid. Wael Massrieh and Anne Pierre Charlot helped in the early phase of this project. Volker Blank acknowledges the receipt of a Charles O Monat Award from McGill University. Grégory Chevillard was supported by a Fonds Québecois de Recherche sur la Nature et les Technologies (FQRNT) fellowship. This research was funded by grants from the Hospital for Sick Children Foundation/CIHR Institute for Child Health and Development and Cancer Research Society Inc. to Volker Blank. The authors declare that there is no conflict of interest that would prejudice the impartiality of this scientific work.

\section{References}

Ackerman WET, Rovin BH \& Kniss DA 2004 Epidermal growth factor and interleukin-1 $\beta$ utilize divergent signaling pathways to synergistically upregulate cyclooxygenase-2 gene expression in human amnion-derived WISH cells. Biology of Reproduction 71 2079-2086.

Aguan K, Carvajal JA, Thompson LP \& Weiner CP 2000 Application of a functional genomics approach to identify differentially expressed genes in human myometrium during pregnancy and labour. Molecular Human Reproduction 6 1141-1145.

Ainbinder E, Revach M, Wolstein O, Moshonov S, Diamant N \& Dikstein R 2002 Mechanism of rapid transcriptional induction of tumor necrosis factor alpha-responsive genes by NF-кB. Molecular and Cellular Biology 22 6354-6362.

Arntzen KJ, Kjollesdal AM, Halgunset J, Vatten L \& Austgulen R 1998 TNF, IL-1, IL-6, IL-8 and soluble TNF receptors in relation to chorioamnionitis and premature labor. Journal of Perinatal Medicine 26 17-26.

Assi F, Fruscio R, Bonardi C, Ghidini A, Allavena P, Mantovani A \& Locatelli A 2007 Pentraxin 3 in plasma and vaginal fluid in women with preterm delivery. British Journal of Obstetrics and Gynaecology 114 143-147. 
Bartlett SR, Sawdy R \& Mann GE 1999 Induction of cyclooxygenase-2 expression in human myometrial smooth muscle cells by interleukin1 beta: involvement of $\mathrm{p} 38$ mitogen-activated protein kinase. Journal of Physiology 520 399-406.

Bethin KE, Nagai Y, Sladek R, Asada M, Sadovsky Y, Hudson TJ \& Muglia LJ 2003 Microarray analysis of uterine gene expression in mouse and human pregnancy. Molecular Endocrinology 17 1454-1469.

Breviario F, d'Aniello EM, Golay J, Peri G, Bottazzi B, Bairoch A, Saccone S, Marzella R, Predazzi V, Rocchi M et al. 1992 Interleukin-1-inducible genes in endothelial cells. Cloning of a new gene related to C-reactive protein and serum amyloid $\mathrm{P}$ component. Journal of Biological Chemistry $26722190-22197$.

Cario-Toumaniantz C, Reillaudoux G, Sauzeau V, Heutte F, Vaillant N, Finet M, Chardin P, Loirand G \& Pacaud P 2003 Modulation of RhoA Rho kinase-mediated $\mathrm{Ca}^{2+}$ sensitization of rabbit myometrium during pregnancy - role of Rnd3. Journal of Physiology 552 403-413.

Challis JR, Sloboda DM, Alfaidy N, Lye SJ, Gibb W, Patel FA, Whittle WL \& Newnham JP 2002 Prostaglandins and mechanisms of preterm birth. Reproduction 124 1-17.

Charpigny G, Leroy MJ, Breuiller-Fouche M, Tanfin Z, Mhaouty-Kodja S, Robin P, Leiber D, Cohen-Tannoudji J, Cabrol D, Barberis C et al. 2003 A functional genomic study to identify differential gene expression in the preterm and term human myometrium. Biology of Reproduction $\mathbf{6 8}$ 2289-2296.

Church GM \& Gilbert W 1984 Genomic sequencing. PNAS 81 1991-1995.

Condon JC, Hardy DB, Kovaric K \& Mendelson CR 2006 Upregulation of the progesterone receptor (PR)-C isoform in laboring myometrium by activation of NF- $\kappa \mathrm{B}$ may contribute to the onset of labor through inhibition of PR function. Molecular Endocrinology 20 764-775.

Cook JL, Zaragoza DB, Sung DH \& Olson DM 2000 Expression of myometrial activation and stimulation genes in a mouse model of preterm labor: myometrial activation, stimulation, and preterm labor. Endocrinology 141 1718-1728.

Devost D \& Zingg HH 2007 Novel in vitro system for functional assessment of oxytocin action. American Journal of Physiology. Endocrinology and Metabolism 292 E1-E6.

Dimitriadis E, White CA, Jones RL \& Salamonsen LA 2005 Cytokines, chemokines and growth factors in endometrium related to implantation. Human Reproduction Update 11 613-630.

Fan Z, Bau B, Yang H \& Aigner T 2004 IL-1 $\beta$ induction of IL- 6 and LIF in normal articular human chondrocytes involves the ERK, p38 and NFKB signaling pathways. Cytokine 28 17-24.

Gimpl G \& Fahrenholz F 2001 The oxytocin receptor system: structure, function, and regulation. Physiological Reviews 81 629-683.

Girotti M \& Zingg HH 2003 Gene expression profiling of rat uterus at different stages of parturition. Endocrinology 144 2254-2265.

Goldenberg RL, Hauth JC \& Andrews WW 2000 Intrauterine infection and preterm delivery. New England Journal of Medicine 342 1500-1507.

Gomez R, Romero R, Edwin SS \& David C 1997 Pathogenesis of preterm labor and preterm premature rupture of membranes associated with intraamniotic infection. Infectious Disease Clinics of North America 11 135-176.

Ha WY, Li XJ, Yue PY, Wong DY, Yue KK, Chung WS, Zhao L, Leung PY, Liu L \& Wong RN 2006 Gene expression profiling of human synovial sarcoma cell line (Hs701.T) in response to IL-1 $\beta$ stimulation. Inflammation Research 55 293-299.

Havelock JC, Keller P, Muleba N, Mayhew BA, Casey BM, Rainey WE \& Word RA 2005 Human myometrial gene expression before and during parturition. Biology of Reproduction 72 707-719.

Hirsch E, Filipovich Y \& Mahendroo M 2006 Signaling via the type I IL-1 and TNF receptors is necessary for bacterially induced preterm labor in a murine model. American Journal of Obstetrics and Gynecology 194 1334-1340.

Huang HY 2006 The cytokine network during embryo implantation. Chang Gung Medical Journal 29 25-36.

Keelan JA, Blumenstein M, Helliwell RJA, Sato TA, Marvin KW \& Mitchell MD 2003 Cytokines, prostaglanding and parturition - a review. Placenta 17 S33-S46.

Kimura T, Ivell R, Rust W, Mizumoto Y, Ogita K, Kusui C, Matsumura Y, Azuma C \& Murata Y 1999 Molecular cloning of human MafF homologue, which specifically binds to the oxytocin receptor gene in term myometrium. Biochemical and Biophysical Research Communications 264 86-92.

Krikos A, Laherty CD \& Dixit VM 1992 Transcriptional activation of the tumor necrosis factor alpha-inducible zinc finger protein, A20, is mediated by $\kappa \mathrm{B}$ elements. Journal of Biological Chemistry 267 17971-17976.

Lappas M, Permezel M, Georgiou HM \& Rice GE 2002 Nuclear factor $\kappa B$ regulation of proinflammatory cytokines in human gestational tissues in vitro. Biology of Reproduction 67 668-673.

Legrand-Poels S, Schoonbroodt S \& Piette J 2000 Regulation of interleukin6 gene expression by pro-inflammatory cytokines in a colon cancer cell line. Biochemical Journal 349 765-773.

Lin R, Yang L, Nakhaei P, Sun Q, Sharif-Askari E, Julkunen I \& Hiscott 2006 Negative regulation of the retinoic acid-inducible gene I-induced antiviral state by the ubiquitin-editing protein A20. Journal of Biological Chemistry 281 2095-2103.

Madsen G, Zakar T, Ku CY, Sanborn BM, Smith R \& Mesiano S 2004 Prostaglandins differentially modulate progesterone receptor-A and $-B$ expression in human myometrial cells: evidence for prostaglandininduced functional progesterone withdrawal. Journal of Clinical Endocrinology and Metabolism 89 1010-1013.

Massrieh W, Derjuga A, Doualla-Bell F, Ku CY, Sanborn BM \& Blank V 2006 Regulation of the MAFF transcription factor by proinflammatory cytokines in myometrial cells. Biology of Reproduction $\mathbf{7 4}$ 699-705.

Mitchell MD, Edwin SS, Lundin-Schiller S, Silver RM, Smotkin D \& Trautman MS 1993 Mechanism of interleukin-1 beta stimulation of human amnion prostaglandin biosynthesis: mediation via a novel inducible cyclooxygenase. Placenta 14 615-625.

Monga M, Ku CY, Dodge K \& Sanborn BM 1996 Oxytocin-stimulated responses in a pregnant human immortalized myometrial cell line. Biology of Reproduction 55 427-432.

Park JS, Park CW, Lockwood CJ \& Norwitz ER 2005 Role of cytokines in preterm labor and birth. Minerva Ginecologica 57 349-366.

Rauk PN \& Chiao JP 2000 Interleukin-1 stimulates human uterine prostaglandin production through induction of cyclooxygenase-2 expression. American Journal of Reproductive Immunology $\mathbf{4 3}$ 152-159.

Romero R, Brody DT, Oyarzun E, Mazor M, Wu YK, Hobbins JC \& Durum SK 1989 Infection and labor. III. Interleukin-1: a signal for the onset of parturition. American Journal of Obstetrics and Gynecology 160 1117-1123.

Romero R, Espinoza J, Goncalves LF, Kusanovic JP, Friel LA \& Nien JK 2006 Inflammation in preterm and term labour and delivery. Seminars in Fetal and Neonatal Medicine 11 317-326.

Rossi M, Sharkey AM, Vigano P, Fiore G, Furlong R, Florio P, Ambrosini G, Smith SK \& Petraglia F 2005 Identification of genes regulated by interleukin-1 $\beta$ in human endometrial stromal cells. Reproduction 130 721-729.

Sadowsky DW, Adams KM, Gravett MG, Witkin SS \& Novy MJ 2006 Preterm labor is induced by intraamniotic infusions of interleukin-1 $\beta$ and tumor necrosis factor-alpha but not by interleukin- 6 or interleukin-8 in a nonhuman primate model. American Journal of Obstetrics and Gynecology 195 1578-1589.

Saji F, Samejima Y, Kamiura S, Sawai K, Shimoya K \& Kimura T 2000 Cytokine production in chorioamnionitis. Journal of Reproductive Immunology 47 185-196.

Sanborn BM 2001 Hormones and calcium: mechanisms controlling uterine smooth muscle contractile activity. The Litchfield Lecture. Experimental Physiology 86 223-237.

Schmid B, Wong S \& Mitchell BF 2001 Transcriptional regulation of oxytocin receptor by interleukin-1 $\beta$ and interleukin-6. Endocrinology 142 1380-1385.

Shlykov SG, Yang M, Alcorn JL \& Sanborn BM 2003 Capacitative cation entry in human myometrial cells and augmentation by hTrpC3 overexpression. Biology of Reproduction 69 647-655.

Slattery MM \& Morrison JJ 2002 Preterm delivery. Lancet 360 1489-1497.

Soloff MS, Cook DL Jr, Jeng YJ \& Anderson GD 2004 In situ analysis of interleukin-1-induced transcription of cox-2 and il-8 in cultured human myometrial cells. Endocrinology 145 1248-1254. 
Suzuki Y, Yamamoto T, Kojima K, Tanemura M, Tateyama H \& Suzumori K 2006 Evaluation levels of cytokines in amniotic fluid of women with intrauterine infection in the early second trimester. Fetal Diagnosis and Therapy 21 45-50.

Tribe RM, Moriarty P, Dalrymple A, Hassoni AA \& Poston L 2003 Interleukin- $1 \beta$ induces calcium transients and enhances basal and store operated calcium entry in human myometrial smooth muscle. Biology of Reproduction 68 1842-1849.

Wertz IE, O'Rourke KM, Zhou H, Eby M, Aravind L, Seshagiri S, Wu P, Wiesmann C, Baker R, Boone DL et al. 2004 De-ubiquitination and ubiquitin ligase domains of A20 downregulate NF- $\kappa B$ signalling. Nature 430 694-699.

Wilson RJ, Allen MJ, Nandi M, Giles H \& Thornton S 2001 Spontaneous contractions of myometrium from humans, nonhuman primate and rodents are sensitive to selective oxytocin receptor antagonism in vitro. British Journal of Obstetrics and Gynaecology 108 960-966.

Xu Y, Kiningham KK, Devalaraja MN, Yeh CC, Majima H, Kasarskis EJ \& St Clair DK 1999 An intronic NF-KB element is essential for induction of the human manganese superoxide dismutase gene by tumor necrosis factor- $\alpha$ and interleukin-1 $\beta$. DNA and Cell Biology 18 709-722.

Zaga V, Estrada-Gutierrez G, Beltran-Montoya J, Maida-Claros R, Lopez-Vancell R \& Vadillo-Ortega F 2004 Secretions of interleukin$1 \beta$ and tumor necrosis factor alpha by whole fetal membranes depend on initial interactions of amnion or choriodecidua with lipopolysaccharides or group B streptococci. Biology of Reproduction 71 1296-1302.

Zaragoza DB, Wilson RR, Mitchell BF \& Olson DM 2006 The interleukin 1beta-induced expression of human prostaglandin F2 $\alpha$ receptor messenger RNA in human myometrial-derived ULTR cells requires the transcription factor, NFאB. Biology of Reproduction 75 697-704.

Received 20 June 2007

First decision 24 August 2007

Accepted 7 September 2007 